\title{
Analisis Pengaruh Kinerja Keuangan, Growth Opportunity Dan Ukuran Perusahaan Terhadap Struktur Modal Dan Nilai Perusahaan
}

\author{
Irrofatun Kusna $^{1^{*}}$, Erna Setijani ${ }^{1}$ \\ ${ }^{1}$ Fakultas Ekonomi dan Bisnis, Universitas Merdeka Malang \\ *irrofatunkusna@gmail.com
}

\begin{abstract}
This research aims to analyze the influence of liquidity, profitability, growth opportunity, company size and capital structure to company value. This research population is food and beverage companies listed in Indonesian Stock Exchange period 2012 - 2016. The technique sampling is a purposive sampling as nine companies. Data analysis uses SmartPLS. The result shows that growth opportunity and company size have a positive and significant influence to company value. Profitability and capital structure have a negative and significant influence to company value. Liquidity has a positive and not significant influence to company value. Liquidity and profitability have a negative and significant influence to capital structure. Growth opportunity and company size have a positive but not significant influence to capital structure. Capital structure as an intervening variable from liquidity and profitability to company value, but not for growth opportunity and company size to company value.
\end{abstract}

Keywords: Company Size, Capital Structure, Company Value, Growth Opportunity, Liquidity, Profitability

https://doi.org/10.26905/jmdk.v6i1.2155

\section{PENDAHULUAN}

Pada dasarnya tujuan perusahaan adalah untuk memaksimumkan kesejahteraan bagi para pemegang sahamnya melalui keputusan investasi, pembelanjaan (pendanaan) dan pengalokasian laba yang menyangkut kebijakan dividen yang ditunjukkan dari harga saham di pasar modal. Harga saham suatu perusahaan yang semakin tinggi maka akan meningkatkan kesejahteraan pemilik saham. Harga pasar saham juga mengindikasikan nilai perusahaan, dengan semakin tingginya nilai perusahaan, maka harga pasar saham perusahaan juga meningkat (Sudana, 2015: 164).

Nilai perusahaan sangat penting karena menunjukkan kinerja perusahaan yang dapat mempengaruhi persepsi investor dan berdampak pada keinginan untuk berinvestasi pada suatu perusahaan. Nilai perusahaan akan meningkat ketika perusahaan menggunakan hutang dengan proporsi yang tinggi dengan adanya pajak di dalamnya, tetapi pada titik tertentu nilai perusahaan akan menurun ketika proporsi hutang dalam struktur modal perusahaan meningkat. Manajer keuangan harus dapat memutuskan struktur modal yang optimal yang dapat memberikan keuntungan untuk perusahaan. Struktur modal yang optimal merupakan struktur modal yang mengoptimalkan antara risiko dan return sehingga memaksimumkan harga saham (Brigham dan Weston, 2001: 150). 
Setiap perusahaan menetapkan struktur modal dengan memperhitungkan berbagai aspek atas dasar rencana strategis pemilik, kemungkinan akses dana, keberanian perusahaan menanggung risiko, serta analisis biaya dan manfaat yang diperoleh dari tiap sumber dana. Dimana sumber dana perusahaan berasal dari internal dan eksternal perusahaan. Sumber dana yang berasal dari internal perusahaan yaitu modal saham disetor dan laba ditahan, sedangkan sumber dana eksternal berasal dari pinjaman dana pihak ketiga yaitu kreditur dan investor. Ketika modal sendiri yang dimiliki perusahaan tidak dapat memenuhi kebutuhan operasionalnya secara optimal, maka perusahaan dapat membiayai investasinya dengan pendanaan dari luar melalui hutang. Pecking order theory menjelaskan bahwa perusahaan menentukan hierarki sumber dana yang digunakan. Dimana investasi akan dibiayai dari sumber dana yang termurah yaitu sumber dana internal (laba ditahan), kemudian penerbitan hutang baru, hingga saham sebagai sumber terakhir.

Perusahaan yang sudah berstatus terbuka (go public) dapat menggunakan pendanaan modal sendiri yang berupa saham dan atau hutang kepada pihak ketiga atau bahkan mendapatkan pendanaan yang lebih besar dengan pertimbangan menjual sahamnya kepada masyarakat luas. Perusahaan harus terbuka akan semua informasi tentang perusahaan kepada publik khususnya investor yang telah membeli saham perusahaan serta kepada pihak-pihak lain (stakeholders).

Salah satu media analisis bagi para pemegang saham untuk mengetahui kinerja keuangan perusahaan adalah laporan keuangan tersebut. Kinerja keuangan yang baik mampu memberikan return yang tinggi bagi pemegang saham. Kinerja keuangan perusahaan dapat dinilai dari tingkat likuiditas dan profitabilitas perusahaan.

Likuiditas adalah rasio yang digunakan sebagai acuan pengukuran kemampuan perusahaan dalam pemenuhan kewajiban jangka pendek. Tingkat rasio likuiditas yang tinggi mengindikasikan semakin baik kemampuan perusahaan dalam memenuhi kewajiban jangka pendeknya. Sehingga investor tidak merasa takut perusahaan mengalami kesulitan dalam memenuhi kewajibannya dan perusahaan akan mendapat kepercayaan dari investor untuk menanamkan dana di perusahaan.

Profitabilitas adalah rasio yang digunakan untuk mengukur kemampuan perusahaan memperoleh laba dalam periode waktu tertentu. Profitabilitas yang besar akan menarik minat investor untuk menanamkan dananya pada perusahaan dikarenakan investor mempunyai anggapan bahwa return yang akan dihasilkan juga akan besar.

Peluang pertumbuhan (growth opportunity) adalah salah satu faktor penting lain yang mempengaruhi nilai perusahaan. Growth opportunity adalah merupakan peluang pertumbuhan suatu perusahaan di masa depan (Mai dalam Hermuningsih, 2013). Baiknya kondisi perutaran keuangan perusahaan ditandai adanya peluang pertumbuhan perusahaan yang positif. Pertumbuhan perusahaan yang tinggi memungkinkan perusahaan untuk melakukan perluasan usaha

Dengan nilai growth opportunity yang tinggi, perusahaan diharapkan mampu untuk mencapai dan menghasilkan keuntungan yang tinggi dimasa yang akan datang. Growth opportunity yang tinggi dapat dijadikan sebagai analisis tercapainya kemakmuran para pemegang saham.

Ukuran perusahaan merupakan faktor penting lain dalam meningkatkan nilai perusahaan. Setiap perusahaan mempunyai ukuran yang berbeda, semakin besar ukuran suatu perusahaan maka semakin besar pula modal yang diinvestasikan di berbagai jenis usaha. Semakin besar ukuran perusahaan maka akan lebih mudah untuk memperoleh dana yang digunakan untuk operasional perusahaan. Perusahaan yang besar dengan mudah mendapatkan akses ke pasar modal dikarenakan perusahaan mempunyai fleksibilitas dan kemampuan untuk mengumpulkan kan dana yang lebih besar. Hal tersebut dapat ditunjukkan dari besarnya total kekayaan yang dimiliki perusahaan, 
total kekayaan inilah yang membuat kepercayaan pihak eksternal saat akan menginvestasikan dananya.

Di Indonesia, sektor saham yang paling diminati oleh investor adalah sektor barang konsumsi. Sektor ini menarik untuk diteliti karena masyarakat tidak lepas dari industri barang konsumsi untuk memenuhi kebutuhan sehari-hari, hal tersebut dapat meningkatkan harga pasar saham perusahaan dikarenakan banyak investor yang tertarik untuk berinvestasi di sektor barang konsumsi. Salah satu dari sektor barang konsumsi yaitu perusahaan makanan dan minuman , dimana saham perusahaan di sektor ini banyak diminati oleh investor dikarenakan kinerja perusahaan yang menunjukkan kenaikkan.

Penelitian ini untuk mengetahui seberapa besar pengaruh kinerja keuangan, peluang pertumbuhan perusahaan (growth opportunity) dan ukuran perusahaan terhadap struktur modal dan nilai perusahaan pada perusahaan makanan dan minuman yang terdaftar di Bursa Efek Indonesia. Variabelvariabel di atas dapat digunakan oleh perusahaan untuk mengambil kebijakankebijakan terkait kelangsungan perusahaan.

\section{METODE}

Kerangka konseptual penelitian ini adalah sebagai berikut:

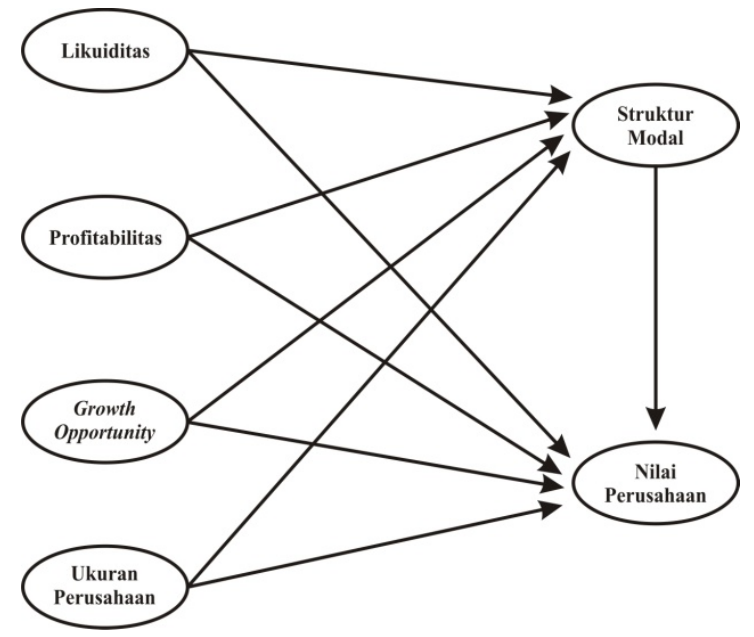

Gambar 1. Kerangka Konseptual Penelitian
Definisi operasional variabel penelitian ini adalah sebagai berikut:

a. Likuiditas (X1) : digunakan untuk mengukur besarnya aktiva lancar yang dimiliki perusahaan dalam memenuhi kewajiban lancar yang jatuh tempo. Indikator pengukuran likuiditas dalam penelitian ini adalah sebagai berikut:

- X1.1 : Current Ratio

- X1.2 : Quick Ratio

- X1.3 : Cash Ratio

b. Profitabilitas (X2) : kemampuan perusahaan dalam memperoleh laba pada periode waktu tertentu. Indikator pengukuran profitabilitas untuk penelitian ini adalah sebagai berikut:

- X2.1 : Net Profit Margin

- X2.2 : Return on Assets (ROA)

- X2.3 : Return on Equity (ROE)

c. Growth Opportunity (X3) : adalah peluang pertumbuhan perusahaan di masa yang akan datang dan dapat dijadikan sebagai analisis tercapainya kemakmuran para pemegang saham. Growth opportunity dalam penelitian ini diukur dengan indikator sebagai berikut:

- X3.1 : Pertumbuhan Aktiva

- X3.2 : Market to Books Total Equity

d. Ukuran Perusahaan (X4) : digunakan untuk mempertimbangkan besarnya kebijakan pendanaan. Indikator ukuran perusahaan dalam penelitian ini sebagai berikut:

- X4.1 : Total Aset

- X4.2 : Total Penjualan

e. Struktur Modal (Y1) : merupakan komposisi pendanaan perusahaan yang berhubungan antara risiko dan return. Indikator pengukuran struktur modal dalam penelitian ini adalah sebagai berikut:

- Y1.1 : Debt Ratio

- Y1.2 : Debt to Equity Ratio

f. Nilai Perusahaan (Y2) : merupakan cerminan dari harga pasar saham suatu perusahaan. Indikator nilai perusahaan dalam penelitian ini adalah sebagai berikut:

- Y2.1 : Price to Book Value 
- Y2.2 : Price Earning Ratio

- Y2.3 : Rasio Tobins’Q

Objek yang diteliti yaitu perusahaan makanan dan minuman yang go public dan terdaftar di Bursa Efek Indonesia (BEI). Teknik purposive sampling digunakan dalam pengambilan sampel pada penelitian ini berdasarkan kriteria - kriteria tertentu. Kriteria tersebut adalah :

a. Seluruh perusahaan makanan dan minuman yang go pulic dan terdaftar di Bursa Efek Indonesia dari tahun 2012 2016.

b. Perusahaan manakan dan minuman yang IPO (Initial Public Offering) pada tahun 2011 kebawah.

c. Perusahaan manakan dan minuman yang mempublikasi Laporan Keuangan secara lengkap dari tahun 2012 - 2016 dan memiliki tahun buku berakhir tanggal 31 Desember.

d. Perusahaan yang tidak memiliki data outlier.

e. Perusahaan yang tidak menderita kerugian selama periode penelitian yakni dari tahun 2012 - 2016.

Berdasarkan kriteria di atas, maka perusahaan yang menjadi sampel dalam penelitian ini berjumlah 9 perusahaan manakan dan minuman. Teknik pengumpulan data dalam penelitian ini adalah dengan mempelajari dan menganalisis data berdasarkan Laporan Keuangan perusahaan yang menjadi sampel dalam penelitian. Analisis data dalam penelitian ini diuji dengan menggunakan program SmartPLS versi 3.0.

Dalam menganalisis data dengan PLS terdapat beberapa langkah analisis.

\section{Model Pengukuran (Outer Model)}

Outer model digunakan untuk mengetahui validitas dan reliabilitas yang menghubungkan indikator dengan variabel latennya. Berikut beberapa komponen analisis yang dapat digunakan antara lain:

a. Convergent Validity
Nilai Convergent validity berdasarkan korelasi antara item score/component score dengan construct score. Nilai korelasi antara indikator dengan konstruk atau variabel latennya diharapkan lebih dari 0,5.

b. Discriminant Validity

Nilai Discriminant validity berdasarkan cross loading pengukuran dengan konstruk. Discriminant validity dapat juga membandingkan nilai square root of Average Variance Extracted (AVE) setiap konstruk dengan korelasi antara konstruk lainnya dalam model. Direkomendasikan nilai AVE lebih besar dari 0,50 (Ghozali, 2008).

c. Composite Reliability

Composite reliability dapat dikatakan memiliki reliabilitas yang tinggi jika nilai lebih besar dari 0,7. Uji reliabilitas dapat dilakukan dengan melihat nilai cronbach alpha dan cronbach alpha dikatakan baik apabila nilai lebih besar dari 0,7 .

\section{Model Struktural (Inner Model)}

Ada beberapa parameter pengujian model struktural (inner model) diantaranya sebagai berikut:

a. R-Square

Nilai R-square adalah koefisien determinasi pada variabel endogen. Nilai R-square sebesar 0,67 (kuat), 0,33 (moderat) dan 0,19 (lemah).

b. Path Coefficients

Path coefficients merupakan nilai koefisien jalur atau besarnya pengaruh konstruk laten.

\section{HASIL DAN PEMBAHASAN}

Hasil

\section{Pengujian Model Pengukuran (Outer Model)}

\section{Convergent Validity}

Berdasarkan hasil pengujian validitas konvergen diketahui bahwa terdapat satu indikator yang tidak memenuhi kriteria yakni pertumbuhan aktiva (PA) yang merupakan indikator dari growth opportunity sehingga 
dinyatakan tidak valid. Dimana nilai yang diperoleh sebesar 0,434 $(<0,5)$.

Sehingga dilakukan pengujian kembali dengan mengeluarkan indikator PA dengan tujuan dapat meningkatkan skor pengukuran model (outer loading) dan skor composite reliability dari variabel growth opportunity.

Tabel 1. Uji Convergent Validity Kedua

\begin{tabular}{lccc}
\hline Indikator & $\begin{array}{c}\text { Outer } \\
\text { Loading }\end{array}$ & $\begin{array}{c}\text { Nilai } \\
\text { Kritis }\end{array}$ & $\begin{array}{c}\text { Evaluasi } \\
\text { Model }\end{array}$ \\
\hline CR & 0,953 & & Valid \\
QR & 0,986 & & Valid \\
CsR & 0,954 & & Valid \\
NPM & 0,890 & & Valid \\
ROA & 0,949 & & Valid \\
ROE & 0,881 & & Valid \\
MTBE & 1,000 & \multirow{2}{*}{0,5} & Valid \\
TA & 0,994 & & Valid \\
TP & 0,992 & & Valid \\
DR & 0,995 & & Valid \\
DER & 0,993 & & Valid \\
PBV & 0,978 & & Valid \\
PER & 0,938 & & Valid \\
Tobin'Q & 0,973 & & Valid \\
\hline
\end{tabular}

Sumber : data sekunder diolah, 2017

Setelah dilakukan pengujian kembali dengan indikator PA dikeluarkan diperoleh hasil bahwa setiap indikator dari masing masing variabel likuiditas, profitabilitas, growth opportunity, ukuran perusahaan, struktur modal dan nilai perusahaan memiliki nilai lebih dari 0,5 sampai lebih dari 0,7. Sehingga indikator dari masing - masing variabel memiliki tingkat validitas yang tinggi.

\section{Discriminant Validity}

Berdasarkan hasil analisis diketahui bahwa model memiliki nilai lebih dari 0,5. Sehingga dapat dikatakan bahwa semua konstruk atau variabel laten dalam penelitian ini memiliki discriminant validity yang baik. Hasil tersebut disajikan pada tabel berikut:

Tabel 2. Nilai Average Variance Extracted (AVE)

\begin{tabular}{lccc}
\hline \multicolumn{1}{c}{ Variabel } & AVE & $\begin{array}{c}\text { Nilai } \\
\text { Kritis }\end{array}$ & $\begin{array}{c}\text { Evaluasi } \\
\text { Model }\end{array}$ \\
\hline Likuiditas & 0,930 & & Valid \\
$\begin{array}{l}\text { Profitabilitas } \\
\text { Growth }\end{array}$ & 0,823 & & Valid \\
$\begin{array}{l}\text { Opportunity } \\
\text { Ukuran }\end{array}$ & 1,000 & & Valid \\
$\begin{array}{l}\text { Perusahaan } \\
\text { Struktur Modal }\end{array}$ & 0,987 & $>0,988$ & Valid \\
$\begin{array}{l}\text { Nilai } \\
\text { Perusahaan }\end{array}$ & 0,928 & & Valid \\
\hline
\end{tabular}

Sumber : data sekunder diolah, 2017

\section{Uji Reliabilitas}

Tabel 3. Nilai Cronbach's Alpha dan Composite Reliability

\begin{tabular}{lcc}
\hline \multicolumn{1}{c}{ Variabel } & $\begin{array}{c}\text { Cronbach's } \\
\text { Alpha }\end{array}$ & $\begin{array}{c}\text { Composite } \\
\text { Reliability }\end{array}$ \\
\hline Likuiditas & 0,962 & 0,976 \\
Profitabilitas & 0,894 & 0,933 \\
$\begin{array}{l}\text { Growth } \\
\text { Opportunity }\end{array}$ & 1,000 & 1,000 \\
Ukuran & & \\
Perusahaan & 0,987 & 0,993 \\
Struktur Modal & 0,988 & 0,994 \\
Nilai Perusahaan & 0,961 & 0,975 \\
\hline
\end{tabular}

Sumber : data sekunder diolah, 2017

Dari tabel 3 diatas diketahui bahwa nilai cronbach's alpha dari masing - masing konstruk yakni likuiditas, profitabilitas, growth opportunity, ukuran perusahaan, struktur modal dan nilai perusahaan lebih dari 0,7 dan nilai composite reliability dari masing - masing konstruk juga lebih besar dari 0,7. Sehingga dapat disimpulkan bahwa semua konstruk memiliki reliabilitas yang tinggi.

\section{Pengujian Model Struktural (Inner Model)}

Berdasarkan hasil pengujian inner model diperoleh nilai R-Square variabel nilai perusahaan adalah sebesar 0,989. Hal ini berarti variabel likuiditas, profitabilitas, growth opportunity, ukuran perusahaan dan struktur modal mampu menjelaskan variabel nilai perusahaan sebesar 98,9\%.

Sedangkan nilai R-Square variabel struktur modal adalah sebesar 0,442. Hal ini berarti 
variabel likuiditas, profitabilitas, growth opportunity dan ukuran perusahaan mampu menjelaskan variabel struktur modal sebesar $44,2 \%$.

Tabel 4. Hasil Pengujian Hipotesis Langsung

\begin{tabular}{|c|c|c|c|c|}
\hline & $\begin{array}{c}\text { Origina } \\
1 \\
\text { Sample }\end{array}$ & $\begin{array}{c}\mathbf{T} \\
\text { Statisti } \\
\text { CS }\end{array}$ & $\begin{array}{c}\mathbf{P} \\
\text { Valu } \\
\text { es } \\
\end{array}$ & $\begin{array}{c}\text { Keterang } \\
\text { an }\end{array}$ \\
\hline $\begin{array}{l}\text { Likuiditas -> } \\
\text { Nilai } \\
\text { Perusahaan }\end{array}$ & 0,024 & 1,003 & 0,316 & $\begin{array}{c}\text { Tidak } \\
\text { Signifika } \\
\text { n }\end{array}$ \\
\hline $\begin{array}{l}\text { Profitabilitas -> } \\
\text { Nilai } \\
\text { Perusahaan }\end{array}$ & $\begin{array}{c}- \\
0,238\end{array}$ & 5,676 & 0,000 & $\begin{array}{c}\text { Signifika } \\
\mathrm{n}\end{array}$ \\
\hline $\begin{array}{l}\text { Growth } \\
\text { Opportunity -> } \\
\text { Nilai } \\
\text { Perusahaan }\end{array}$ & 1,084 & 32,322 & 0,000 & $\underset{n}{\text { Signifika }}$ \\
\hline $\begin{array}{l}\text { Ukuran } \\
\text { Perusahaan -> } \\
\text { Nilai } \\
\text { Perusahaan }\end{array}$ & 0,048 & 2,779 & 0,006 & $\begin{array}{c}\text { Signifika } \\
\mathrm{n}\end{array}$ \\
\hline $\begin{array}{l}\text { Struktur Modal } \\
\text {-> Nilai } \\
\text { Perusahaan }\end{array}$ & $\begin{array}{c}- \\
0,190\end{array}$ & 4,285 & 0,000 & $\begin{array}{c}\text { Signifika } \\
\mathrm{n}\end{array}$ \\
\hline $\begin{array}{l}\text { Likuiditas -> } \\
\text { Struktur Modal }\end{array}$ & $\begin{array}{c}- \\
0,452\end{array}$ & 2,573 & 0,010 & $\begin{array}{c}\text { Signifika } \\
\mathrm{n}\end{array}$ \\
\hline $\begin{array}{l}\text { Profitabilitas -> } \\
\text { Struktur Modal } \\
\text { Growth }\end{array}$ & 0,442 & 2,468 & 0,014 & $\begin{array}{c}\text { Signifika } \\
\text { n } \\
\text { Tidak }\end{array}$ \\
\hline $\begin{array}{l}\text { Opportunity -> } \\
\text { Struktur Modal } \\
\text { Ukuran }\end{array}$ & 0,267 & 1,665 & 0,097 & $\begin{array}{c}\text { Signifika } \\
\text { n } \\
\text { Tidak }\end{array}$ \\
\hline $\begin{array}{l}\text { Perusahaan -> } \\
\text { Struktur Modal }\end{array}$ & 0,143 & 1,235 & 0,218 & $\begin{array}{c}\text { Signifika } \\
\mathrm{n}\end{array}$ \\
\hline
\end{tabular}

Sumber : data sekunder diolah, 2017

\section{Pengujian Pengaruh Tidak Langsung}

Tabel 5. Hasil Pengujian Hipotesis Tidak Langsung

\begin{tabular}{|c|c|c|c|c|}
\hline & $\begin{array}{c}\text { Origina } \\
\text { l } \\
\text { Sample }\end{array}$ & $\begin{array}{c}\mathbf{T} \\
\text { Statistic } \\
\mathrm{S}\end{array}$ & $\begin{array}{c}\mathbf{P} \\
\text { Valu } \\
\text { es } \\
\end{array}$ & $\begin{array}{c}\text { Keteranga } \\
\mathbf{n}\end{array}$ \\
\hline $\begin{array}{l}\text { Likuiditas -> } \\
\text { Struktur } \\
\text { Modal -> } \\
\text { Nilai } \\
\text { Perusahaan }\end{array}$ & 0,086 & 1,990 & 0,047 & $\begin{array}{c}\text { Signifika } \\
\mathrm{n}\end{array}$ \\
\hline $\begin{array}{l}\text { Profitabilitas } \\
\text {-> Struktur } \\
\text { Modal -> } \\
\text { Nilai } \\
\text { Perusahaan }\end{array}$ & 0,084 & 2,334 & 0,020 & $\begin{array}{c}\text { Signifika } \\
\mathrm{n}\end{array}$ \\
\hline
\end{tabular}

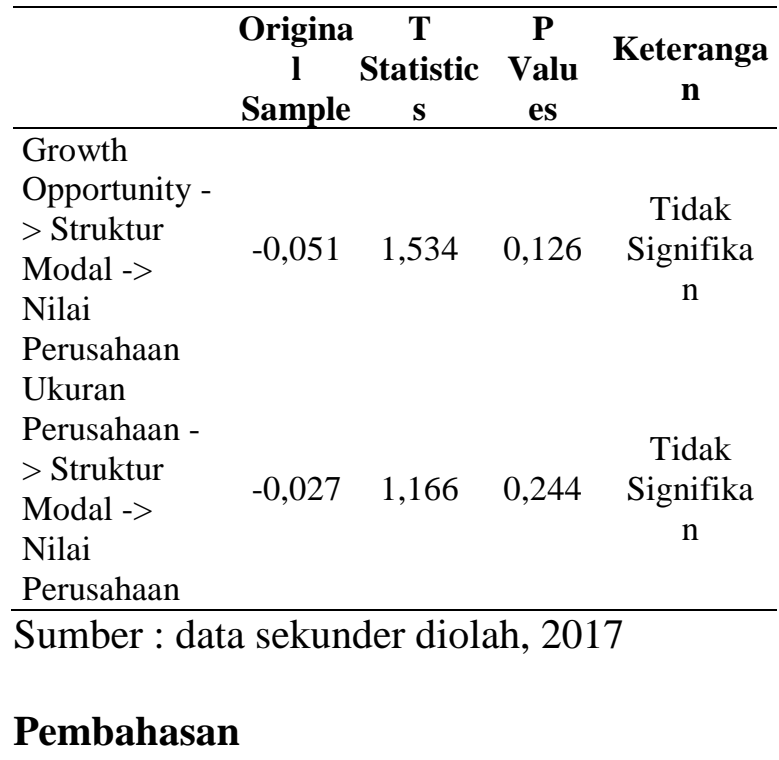

Berdasarkan hasil analisis mengenai pengaruh likuiditas, profitabilitas, growth opportunity dan ukuran perusahaan terhadap struktur modal dan nilai perusahaan pada perusahaan food and beverage periode 2012 - 2016 pada tabel 4 diperoleh hasil bahwa likuiditas perusahaan tidak berpengaruh signifikan terhadap nilai perusahaan. Hal ini dikarenakan tingkat likuiditas perusahaan yang tinggi menunjukkan adanya aktiva yang tidak dimanfaatkan oleh perusahaan secara maksimal dan akan berakibat pada menurunnya nilai perusahaan. Sedangkan tingkat likuiditas perusahaan berpengaruh negatif signifikan terhadap struktur modal. Ketika likuiditas perusahaan naik mengindikasikan bahwa perusahaan mempunyai dana internal yang besar sehingga perusahaan akan menggunakan dana internalnya untuk membiayai operasional perusahaan. Sesuai dengan pecking order theory yang menyatakan bahwa perusahaan lebih menyukai pendanaan dari internal perusahaan dibandingkan dengan hutang dari pihak luar.

Profitabilitas perusahaan berpengaruh negatif signifikan terhadap nilai perusahaan. Hal ini disebabkan karena ketika investor akan berinvestasi pada suatu perusahaan tidak hanya terpaku pada tingkat keuntungan yang dihasilkan perusahaan. Terkadang seorang investor lebih memilih untuk membeli saham perusahaan meskipun tingkat keuntungan perusahaan mengalami 
penurunan karena harga saham perusahaan semakin rendah. Sedangkan profitabilitas mempunyai pengaruh negatif signifikan terhadap struktur modal. Hal ini disebabkan ketika perusahaan memiliki tingkat profitabilitas yang tinggi akan menurunkan tingkat ketergantungan perusahaan terhadap modal dari pihak luar karena perusahaan akan menggunakan sumber pendanaan dari internal perusahaan yang berupa laba bersih atau laba ditahan untuk membiayai operasional perusahaan. Profitabilitas yang meningkat mengindikasikan perusahaan semakin efisien dalam menggunakan seluruh modal yang dimiliki sehingga tidak mengalami kekurangan pendanaan yang menyebabkan perusahaan harus meminjam dana dari pihak luar.

Growth opportunity berpengaruh positif signifikan terhadap nilai perusahaan. Karena ketika perusahaan memiliki peluang pertumbuhan yang tinggi menandakan bahwa pasar menilai tingkat pengembalian dari investasi perusahaan akan lebih besar di masa depan. Peluang pertumbuhan perusahaan memberikan aspek positif kepada investor terkait nilai pasar perusahaan dan mendapatkan kepercayaan dari investor untuk menginvestasikan dananya di perusahaan tersebut dengan harapan akan mendapatkan return yang tinggi di masa yang akan datang, sehingga hal tersebut akan meningkatkan harga saham perusahaan. Growth opportunity berpengaruh positif namun tidak signifikan terhadap struktur modal. Hal ini dikarenakan ketika pertumbuhan perusahaan tinggi maka dana yang dibutuhkan perusahaan akan meningkat, tetapi perusahaan cenderung akan menggunakan dana internal yang dimiliki terlebih dahulu yakni laba bersih dan laba ditahan untuk operasionalnya dibandingkan menggunakan dana dari luar. Dengan demikian ketika pasar menghargai investasi perusahaan tinggi tidak akan berpengaruh terhadap komposisi modal yang digunakan perusahaan.

Ukuran perusahaan mempunyai pengaruh positif signifikan terhadap nilai perusahaan. Ukuran perusahaan yang besar menunjukkan pertumbuhan dan perkembangan perusahaan yang baik. Hal ini ditunjukkan oleh semakin bertambahnya aset yang dimiliki perusahaan dan kondisi penjualan yang meningkat akan menjadi sinyal positif kepada investor untuk berinvestasi di perusahaan tersebut, sehingga akan meningkatkan permintaan saham perusahaan yang menyebabkan harga saham perusahaan naik atau meningkatnya nilai perusahaan. Sedangkan ukuran perusahaan tidak berpengaruh signifikan terhadap struktur modal. Dimana semakin besar ukuran perusahaan maka modal yang dibutuhkan juga akan semakin besar. Tetapi manajemen perusahaan harus dapat memutuskan komposisi dana yang tepat untuk perusahaan sehingga dapat memberikan keuntungan bagi perusahaan. Ketika suatu perusahaan akan menggunakan dana dari eksternal perusahaan maka baik perusahaan besar maupun kecil harus mempertimbangkan berbagai aspek karena hutang yang besar akan memberikan beban berupa bunga pinjaman di masa yang akan datang. Sehingga perusahaan akan menggunakan dana internal terlebih dahulu dibandingkan dana dari eksternal perusahaan dalam operasionalnya.

Struktur modal mempunyai pengaruh signifikan terhadap nilai perusahaan. Artinya ketika struktur modal perusahaan turun dapat meningkatkan nilai perusahaan karena ketika perusahaan menggunakan komposisi hutang dalam jumlah yang wajar mengindikasikan bahwa perusahaan dapat beroperasi secara efisien dan kinerja perusahaan semakin baik. Sehingga dapat meningkatkan kepercayaan investor untuk berinvestasi pada perusahaan tersebut.

Berdasarkan hasil analisis pada tabel 5 diketahui pula bahwa struktur modal menjadi variabel intervening dari likuiditas terhadap nilai perusahaan, yang berarti struktur modal memiliki pengaruh terhadap likuiditas dalam meningkatkan nilai perusahaan. Sesuai dengan signaling theory, perusahaan dapat memberikan sinyal kepada pasar dengan menambah jumlah hutang karena investor memandang bahwa meningkatnya nilai 
perusahaan berasal dari penggunaan hutang yang tinggi. Dengan demikian perusahaan dapat menambah jumlah hutang lancar untuk dapat meningkatkan nilai perusahaan.

Hasil lain menunjukkan bahwa struktur modal menjadi faktor antara pengaruh profitabilitas terhadap nilai perusahaan, yang berarti struktur modal memiliki pengaruh terhadap profitabilitas dalam meningkatkan nilai perusahaan. Perusahaan dengan profit yang tinggi akan dengan mudah memdapatkan pendanaan dari eksternal perusahaan karena perusahaan dinilai memiliki kinerja yang baik dalam menggunakan seluruh modal yang dimiliki yang ditunjukkan dari trend keuntungan perusahaan yang semakin meningkat.

Sehingga untuk meningkatkan nilai perusahaan maka penerbitan hutang dapat dilakukan oleh perusahaan untuk memberikan keyakinan investor bahwa kinerja perusahaan semakin baik yang ditunjukkan dari laba perusahaan yang semakin meningkat. Selain itu, perusahaan dengan profit yang tinggi akan mendapatkan penghematan pajak dengan adanya penggunaan hutang. Dengan demikian dapat disimpulkan bahwa struktur modal memediasi profitabilitas terhadap nilai perusahaan.

Sedangkan struktur modal tidak menjadi variabel intervening dari growth opportunity terhadap nilai perusahaan. Hal ini dapat diartikan bahwa struktur modal tidak memiliki pengaruh terhadap growth opportunity dalam meningkatkan nilai perusahaan. Perusahaan yang memiliki tingkat pertumbuhan tinggi akan dinilai investor memiliki prospek yang baik atau return yang tinggi di masa yang akan datang. Sehingga investor akan menginvestasikan dana yang dimiliki pada perusahaan tersebut dan seiring dengan tingginya permintaan akan saham perusahaan maka akan meningkatkan nilai perusahaan yang tercermin dari harga saham perusahaan yang semakin naik.

Struktur modal juga tidak memediasi ukuran perusahaan terhadap nilai perusahaan. Dimana semakin besar ukuran suatu perusahaan maka total aset yang dimiliki semakin besar dan akan menurunkan penggunaan hutang dalam meningkatkan nilai perusahaan. Selain total aset, dalam penelitian ini ukuran perusahaan di proksi dengan total penjualan. Semakin tinggi penjualan perusahaan mengindikasikan bahwa kinerja perusahaan semakin baik dan akan meningkatkan kepercayaan investor untuk berinvestasi di perusahaan tersebut. Jadi semakin tinggi total aset yang dimiliki perusahaan dan semakin meningkatnya penjualan akan dapat meningkatkan nilai perusahaan tanpa perusahaan memberikan sinyal kepada pasar dengan menggunakan modal eksternal atau hutang dalam operasionalnya.

\section{Kesimpulan}

Penelitian dan analisis yang dilakukan pada perusahaan makanan dan minuman yang terdaftar di Bursa Efek Indonesia periode 2012 - 2016 menunjukkan bahwa nilai perusahaan tidak dipengaruhi secara signifikan oleh likuiditas, akan tetapi dipengaruhi secara negatif signifikan oleh profitabilitas dan struktur modal, sedangkan growth opportunity dan ukuran perusahaan memiliki pengaruh positif signifikan .

Struktur modal dipengaruhi oleh likuiditas dan profitabilitas secara negatif signifikan, sedangkan growth opportunity dan ukuran perusahaan tidak berpengaruh secara signifikan.

Hasil lain diketahui bahwa struktur modal memediasi pengaruh likuiditas terhadap nilai perusahaan dan pengaruh profitabilitas terhadap nilai perusahaan. Tetapi struktur modal tidak memediasi pengaruh growth opportunity terhadap nilai perusahaan dan ukuran perusahaan terhadap nilai perusahaan.

\section{DAFTAR PUSTAKA}

Agustia, Dian. 2011. Pengaruh Profitabilitas dan Likuiditas Terhadap Nilai Perusahaan dengan Struktur Modal Sebagai Variabel Intervening. JAKPI, FEB Universitas Airlangga, 2(1), hal: 43-52. 
Ananda, N.A. Hermanto dan I Nyoman N.A.P. 2016. Pengaruh Profitabilitas, Growth Opportunity Terhadap Nilai Perusahaan dengan Struktur Modal Sebagai Variabel Intervening Pada Perusahaan Property, Real Estate \& Building Construction di BEI Periode 2011 - 2014. Jurnal Magister Manajemen Universitas Mataram, 5(4).

Atiqoh, Zummatul dan Nur Fadjrih Asyik. 2016. Pengaruh Kinerja Keuangan, Size, Pertumbuhan Penjualan dan Kepemilikan Saham Terhadap Struktur Modal. Jurnal Ilmu dan Riset Akuntansi, 5(5).

Dewi, Dewa Ayu Intan Y.M. dan Gede Mertha S. 2017. Pengaruh Profitabilitas, Ukuran Perusahaan dan Aset Pertumbuhan Terhadap Struktur Modal dan Nilai Perusahaan. E-Jurnal Manajemen Universitas Udayana, 6(4), hal: 2222-2252.

Fahmi, Irham. 2012. Analisis Laporan Keuangan. Alfabeta. Bandung.

Fatmah. 2016. Pengaruh Kinerja Keuangan, Struktur Kepemilikan, Ukuran Perusahaan dan Pertumbuhan Perusahaan Terhadap Nilai Perusahaan. Jurnal, FEB Universitas Muhammadiyah, Yogyakarta.

Fitriasari, Dewi dan Deny Arnos Kwary. (trans). James C. Van Horne dan John M. Wachowicz. 2005. Prinsip - Prinsip Manajemen Keuangan. Edisi Keduabelas. Buku Satu. Salemba Empat. Jakarta.

Ghozali, Imam. 2008. Structural Equation Modeling Metode Alternatif dengan Partial Least Square. Edisi Kedua. Badan Penerbit Universitas Diponegoro. Semarang.

Halim, Abdul. 2015. Manajemen Keuangan Bisnis Konsep dan Aplikasinya. Mitra Wacana Media. Jakarta.
Harjito, D. Agus dan Martono. 2010. Manajemen Keuangan. Ekonisia. Yogyakarta.

Hermuningsih, Sri. 2012 ${ }^{1)}$ Pengaruh Profitabilitas, Size Terhadap Nilai Perusahaan dengan Struktur Modal Sebagai Variabel Intervening. Jurnal Siasat Bisnis, 16(2), hal: 232-242. -. 20132). Pengaruh Profitabilitas, Growth Opportunity, Struktur Modal Terhadap Nilai Perusahaan Pada Perusahaan Publik di Indonesia. Buletin Ekonomi Moneter dan Perbankan.

http://annisty.blogspot.co.id/2010/01/analisis -data-menggunakan-partial-least.html

http://www.idx.co.id

http://www.sahamok.com

Husnan, Suad dan Enny Pudjiastuti. 2004. Dasar-Dasar Manajemen Keuangan. UPP AMP YKPN. Yogyakarta.

Kamaludin dan Rini Indriani. 2012. Manajemen Keuangan: Konsep Dasar dan Penerapannya. Edisi Revisi. CV Mandar Maju. Bandung.

Kartini dan Tulus Arianto. 2008. Struktur Kepemilikan, Profitabilitas, Pertumbuhan Aktiva dan Ukuran Perusahaan Terhadap Struktur Modal Pada Perusahaan Manufaktur. Jurnal Keuangan dan Perbankan, 12(1), hal: 11-21.

Kusumajaya, Dewa Kadek Oka. 2011. Pengaruh Struktur Modal dan Pertumbuhan Perusahaan Terhadap Profitabilitas dan Nilai Perusahaan Pada Perusahaan Manufaktur di Bursa Efek Indonesia. Tesis, Universitas Udayana, Denpasar.

Maftukhah, Ida. 2013. Kepemilikan Manajerial, Kepemilikan Institusional dan Kinerja Keuangan Sebagai Penentu Struktur Modal Perusahaan. 
Jurnal Dinamika Manajemen, 4(1), pp: 69-81.

Munawir, S. 2002. Analisa Laporan Keuangan. Edisi Keempat. Cetakan ke13. Liberty. Yogyakarta.

Saraswati, Ratna. (trans). Stephen A. Ross et al. 2015. Pengantar Keuangan Perusahaan. Edisi Global Asia. Buku Satu. Salemba Empat. Jakarta.

Sartono, Agus. 2001. Manajemen Keuangan Teori dan Aplikasi. Edisi Keempat. BPFE-Yogyakarta. Yogyakarta.

Setiyadi. 2007. Pengaruh Company Size, Profitability, dan Institutional Ownership Terhadap CSR Disclousure. Jurnal Ekonomi, Universitas Padjajaran, Bandung.

Shabrina, Alifah. 2015. Kebijakan Dividen Memoderasi Hubungan Struktur Modal dan Growth Opportunity Terhadap Nilai Perusahaan. Jurnal Ilmu \& Riset Akuntansi, 4(10), hal: 1-16.

Sirait, Alfonsus. (trans). Eugene F. Brigham dan J. Fred Weston. 2001. DasarDasar Manajemen Keuangan. Edisi Kesembilan. Jilid Dua. Erlangga. Jakarta.

Sudana, I Made. 2015. Manajemen Keuangan Perusahaan Teori dan Praktik. Edisi Kedua. Erlangga. Jakarta.

Sugiarto. 2009. Struktur Modal, Struktur Kepemilikan Perusahaan, Permasalahan Keagenan \& Informasi Asimetri. Graha Ilmu. Yogyakarta.

Sugiono, Arif dan Edi Untung. 2016. Panduan Praktis Dasar Analisa Laporan Keuangan. PT Grasindo. Jakarta.

Sugiyono. 2016. Metode Penelitian Kuantitatif, Kualitatif, dan $R \& D$. Alfabeta. Bandung.

Syamsuddin, Lukman. 2001. Manajemen Keuangan Perusahaan: Konsep Aplikasi Dalam Perencanan,
Pengawasan dan Pengambilan Keputusan. Edisi Baru. PT Raja Grafindo Persada. Jakarta.

Wibowo, Herman. (trans). Erich A. Helfert. 1997. Teknik Analisis Keuangan. Edisi Kedelapan. Erlangga. Jakarta.

Wulandari, Dwi Retno. 2013. Pengaruh Profitabilitas, Operating Leverage, Likuiditas Terhadap Nilai Perusahaan dengan Struktur Modal Sebagai Variabel Intervening. Accounting Analysis Journal, 3(1), hal: 455-463.

Yanti, Wa Ode Rida. 2017. Pengaruh Ukuran Perusahaan, Hutang, Pertumbuhan Aset dan Likuiditas Terhadap Profitabilitas. Skripsi Fakultas Ekonomi dan Bisnis, Universitas Merdeka Malang.

Yulianto, Ali Akbar. (trans). Eugene F. Brigham dan Joel F. Houston. 2010. Dasar-Dasar Manajemen Keuangan. Edisi Kesepuluh. Buku Satu. Salemba Empat. Jakarta. 